\title{
UJI AKTIVITAS ANTIOKSIDAN DARI EKSTRAK DAUN Tilia kiusiana
}

\section{(Activity Assay of Tilia kiusiana Leaf Extract )}

\author{
Amalia Indah Prihantini' \& Sanro Tachibana ${ }^{2}$ \\ ${ }^{1}$ Balai Penelitian dan Pengembangan Teknologi Hasil Hutan Bukan Kayu, \\ Badan Litbang dan Inovasi, Kementerian Lingkungan Hidup dan Kehutanan, \\ Jl. Dharma Bhakti No.7, Langko, Lingsar, Lombok Barat, NTB 83371, Telp/Fax. (0370) 6573841 \\ ${ }^{2}$ Department of Applied Bioscience, Faculty of Agriculture, Ehime University, 3-5-7 Tarumi, Matsuyama, \\ Ehime, 790-8566, Japan \\ E-mail : amaliaindah2@gmail.com
}

\begin{abstract}
There are many of the world's biodiversity has not been evaluated for any biological activity. To explore the pharmacological potency of nature, the present study investigated antioxidant activity assay of Tilia kiusiana, a Japanese lime tree. Methanolic leaf extract of T. kiusiana was used to analyze the antioxidant assays. The result showed that the extract had moderate activity on antioxidant assays such as DPPH radical scavenging activity $($ IC50 232.76 $\pm 1.13 \mu \mathrm{g} / \mathrm{mL})$, reducing power $(53.33 \pm 1.57 \mathrm{mg}$ $Q E / g$ dry extract); hydrogen peroxide $(304.49 \pm 4.57 \mu \mathrm{g} / \mathrm{mL})$, and $\beta$-karoten $(45.80 \pm 1.68 \mu \mathrm{g} / \mathrm{mL})$. The Total Phenolic Content (TPC) revealed that the extract had low values for gallic acid, quercetin, and rutin equivalents $(49.29 \pm 3.82 \mathrm{mg} Q \mathrm{QE} / \mathrm{g}$ dry extract; $36.57 \pm 3.01 \mathrm{mg}$ QE/g dry extract; $90.44 \pm 7.23 \mathrm{mg}$ $Q E / g$ dry extract, respectively). In conclusion, the present study supported the investigation on discovery and resupply of pharmacological active plant-derived natural products.
\end{abstract}

Keywords : T. kiusiana, antioxidant activity, leafextract

\begin{abstract}
ABSTRAK
Saat ini masih banyak biodiversitas-biodiversitas di dunia yang belum diketahui kemampuan bioaktifnya. Untuk mengetahui potensi farmakologi dari sumber-sumber daya alam tersebut, penelitian ini mempelajari aktivitas antioksidan dari tanaman Tilia kiusiana, pohon jeruk dari Jepang. Ekstrak metanol dari daun T. kiusiana digunakan untuk menganalisis aktivitas antioksidannya. Hasil penelitian menunjukkan bahwa ekstrak tersebut memiliki aktivitas pada uji-uji antioksidan seperti penghambatan radikal DPPH (IC50 232,76 $\pm 1,13 \mu \mathrm{g} / \mathrm{mL}$ ), uji kemampuan reduksi (53,33 $\pm 1,57 \mathrm{mg}$ QE/g ekstrak); uji hidrogen peroksida $(304,49 \pm 4,57 \mu \mathrm{g} / \mathrm{mL})$, and uji pemudaran $\beta$-karoten $(45,80 \pm 1,68 \mu \mathrm{g} / \mathrm{mL})$. Total kandungan senyawa fenolik (TPC) menunjukkan bahwa ekstrak tersebut memiliki nilai yang rendah untuk kandungan setara asam galat $(49,29 \pm 3,82 \mathrm{mg}$ QE/g ekstrak), kuersetin $(36,57 \pm 3,01 \mathrm{mg}$ QE/g ekstrak), dan rutin $(90,44 \pm 7,23 \mathrm{mg}$ QE/g ekstrak). Dapat disimpulkan bahwa T. kiusiana dapat dipertimbangkan sebagai sumber alternatif obat-obatan alami.
\end{abstract}

Kata kunci: T. kiusiana, aktivitas antioksidan, ekstrak daun

\section{PENDAHULUAN}

Beberapa penyakit kronis seperi penyakit hati, stroke, kanker, diabetes melitus merupakan penyakit yang paling menyebabkan kematian, sehingga memerlukan perhatian yang serius untuk mengatasinya. Sementara itu, untuk mengobati penyakit-penyakit pada manusia, pemanfaatan produk yang diekstraksi dari sumberdaya alam menjadi hal menarik dan layak untuk dipertimbangkan. Lebih dari $80 \%$ kandungan obat yang tergabung dalam program penemuan obat di masa lalu dilaporkan berasal dari bahan-bahan di alam (Newman \& Cragg, 2016; Harvey, 2008; Ortholand \& Ganesan, 2004). Hampir separuh dari obat yangditemukan sejak tahun 1981 
hingga 2014 berasal dari bahan alam (Newman \& Cragg, 2016). Berdasarkan publikasi penelitian terkini, terdapat 38 jenis obat yang berasal dari bahan alam dan diterima sebagai obat sejak tahun 2000 hingga 2010 yang berfungsi untuk berbagai indikasi penyakit, antara lain 15 obat untuk penyakit infeksi, 7 obat untuk oncology, neurological disease, 4 obat untuk metabolic disorder, dan 1 untuk diabetes (Brahmachari, 2012). Oleh karena itu, penelitian yang mendalam untuk penemuan dan persediaan obat-obatan alami menjadi sangat penting dilakukan. Obat-obatan alami dapat diperoleh dari sumber-sumber daya alam seperti makanan, tanaman, jamur, hewan, dan organisme laut (Prihantini et al., 2014; Gurnani et al., 2014).

Sumber daya alam di dunia sangat beragam dan memiliki potensi yang tinggi sebagai sumber obat. Banyak obat-obatan tradisional kuno yang diekstrak dari pohon dan tanaman sebagai contoh, morfin sebagai obat analgesik dari tanaman opium, senyawa kuinin antimalarial dari kulit pohon kina, dan obat anti malaria artemisinin dari Artemisia annua, serta combrestatin sebagai senyawa utama untuk obat antikanker yang diisolasi dari ekstrak pohon willow Afrika (Patrick, 2001). Penemuan obat-obatan lainnya dari bahan alam antara lain obat anti kanker seperti podophyllotoxin dari tanaman Podophyllum pelltatum, campothecin dari tanaman Camptotheca acuminate, serta paclitaxel dari tanaman Taxus brevifolia (Gurnani et al., 2014). Evaluasi kemampuan bioaktif dari 14 tanaman sub tropis pun telah dilakukan pada penelitian kami sebelumnya (Prihantini et al., 2014). Meskipun telah ditemukan banyak senyawa potensi obat dari alam dan telah dilakukan studi analisis bioaktivitas dari beragam ekstrak tanaman, masih banyak biodiversitas di dunia ini yang belum dievaluasi aktivitas biologisnya sebagai potensi obat.

Tilia kiusiana merupakan tanaman dari famili Tiliaceae yang tumbuh tegak dengan lambat dan menggugurkan daunnya pada musimnya. Daunnya berwarna hijau muda, bulat telur dengan tepi bergerigi dan menguning di musim gugur sebelum mulai berguguran.
Hingga saat ini, belum banyak referensi yang melaporkan kemampuan bioaktivitas dari tanaman tersebut. Methanol ekstrak dari $T$. kiusiana telah dilaporkan memiliki aktivitas sitotoksik terhadap sel P388. Adapun senyawasenyawa yang diisolasi dari $T$. kiusiana memiliki aktivitas sitotoksik terhadap human promyelocytic leukemia cells (Shimada et al., 2014). Namun, informasi mengenai kemampuan aktivitas antioksidan dari $T$. kiusiana belum dilaporkan. Oleh karena itu, penelitian ini bertujuan mempelajari tentang aktivitas antioksidan dari ekstrak daun $T$. kiusiana, tanaman khas Kyushu, Jepang bagian selatan, sehingga dapat memberikan tambahan informasi dalam dunia farmasi dan upaya penemuan obat-obatan alami baru.

\section{BAHAN DAN METODE}

\section{A. Bahan Penelitian}

Daun T. kiusiana diperoleh di kebun koleksi tanaman Ehime University. Kuersetin, asam galat, rutin, 1,1-diphenyl-2picrylhydrazyl (DPPH), $\beta$-karoten, hidrogen peroksida $\left(\mathrm{H}_{2} \mathrm{O}_{2}\right)$, asam linoleat, Tween40, kalium ferisianida $\left(\mathrm{K}_{3}[\mathrm{Fe}(\mathrm{CN}) 6]\right)$, dan asam trikloroasetat yang digunakan merupakan produksi Wako Pure Chemical Industries Ltd., Osaka, Jepang. Pereaksi Folin-Ciocalteu yang digunakan merupakan produksi Sigma Aldrich, Jepang.

\section{B. Penyiapan Ekstrak}

Sebanyak 300 gr daun T. kiusiana yang segar dan sehat dikeringkan pada suhu ruang, dihancurkan, dan diekstrak dengan metode maserasi menggunakan metanol selama 2 hari. Ekstrak metanol yang dihasilkan kemudian disaring dan diuapkan menggunakan rotary evaporator pada suhu sekitar $40^{\circ} \mathrm{c}$ untuk mendapatkan ekstrak kasar yang pekat. Proses ekstraksi tersebut diulang sebanyak 2 kali hingga ekstrak metanol yang diperoleh berwarna cerah atau transparan. Ekstrak kasar yang telah pekat kemudian dikeringkan dan ditimbang. 


\section{Pengujian Aktivitas Antioksidan}

Pengujian aktivitas antioksidan dilakukan dengan menggunakan uji penghambatan radikal bebas DPPH, uji kemampuan reduksi, uji hidrogen peroksida, uji pemudaran $\beta$-karoten, dan total kandungan fenol.

\section{Uji penghambatan radikal bebas DPPH}

Uji penghambatan radikal DPPH dilakukan dengan menggunakan metode Yen and Chen (1995) dengan sedikit modifikasi. Sampel dalam pelarut metanol pada berbagai konsentrasi dicampur dengan $0,5 \mathrm{~mL}$ dari $1 \mathrm{mM}$ radikal bebas DPPH dalam metanol. Larutan yang sama disiapkan tanpa sampel yang akan digunakan sebagai kontrol. Pengukuran absorban (A) dilakukan dengan spektrofotometer pada panjang gelombang 517 $\mathrm{nm}$ setelah inkubasi larutan pada ruang gelap selama 30 menit. Kuersetin digunakan sebagai standar positif. Persentase aktivitas penangkapan radikal bebas dihitung dengan rumus sebagai berikut.

Persentase aktivitas penangkapan $(\%)=$ (A kontrol-A sampel) /A kontrol x 100\%

\section{Uji kemampuan reduksi}

Uji kemampuan reduksi dilakukan berdasarkan metode Yen dan Chen (1995) dengan sedikit modifikasi. Sebanyak $0,5 \mathrm{~mL}$ sampel dengan berbagai konsentrasi dalam metanol dicampur dengan buffer fosfat $(2,5$ $\mathrm{mL} ; 0,2 \mathrm{M} ; \mathrm{pH} 6,6)$ dan kalium ferisianida $(2,5$ $\mathrm{mL})$. Asam trikloroasetat $(2,5 \mathrm{~mL} ; 10 \%)$ ditambahkan pada campuran setelah 20 menit inkubasi pada suhu $50^{\circ} \mathrm{c}$. Campuran tersebut kemudian disentrifugasi pada $3000 \mathrm{rpm}$ selama 10 menit. Lapisan atas larutan $(2,5 \mathrm{~mL})$ dicampur dengan air suling $(2,5 \mathrm{~mL})$ dan larutan besi klorida $(0,5 \mathrm{~mL} ; 0,1 \%)$. Absorban diukur dengan spektrofotometer pada panjang gelombang $700 \mathrm{~nm}$. Nilai uji dihitung dengan satuan ekuivalen kuersetin.

\section{Uji hidrogen peroksida}

Uji hidrogen peroksida dilakukan berdasarkan metode Ruch et al., (1989) dengan sedikit modifikasi. Sampel dengan bervariasi konsentrasi dicampur dengan buffer fosfat basa (pH 7.4) hingga 3,4 mL. Sebanyak 0,6 mL dari $40 \mathrm{mM}$ hidrogen peroksida ditambahkan ke dalam campuran tersebut dan dibiarkan selama 10 menit. Absorban dari campuran tersebut diukur dengan spektrofotometer pada panjang gelombang $230 \mathrm{~nm}$.

\section{Uji pemudaran $\beta$-karoten}

Uji pemudaran $\beta$-karoten dilakukan menggunakan metode Jayaprakasha et al., (2001) dengan sedikit perubahan. Sebanyak 0,2 $\mathrm{mg} \beta$-karoten, $20 \mathrm{mg}$ linoleic acid, dan $200 \mathrm{mg}$ Tween 40 dicampur dengan kloroform. Setelah tercampur, kloroform diuapkan dengan rotary evaporator pada suhu $40^{\circ} \mathrm{c}$. Campuran yang dihasilkan kemudian dilarutkan dengan air suling dan dikocok dengan perlahan hingga 50 $\mathrm{mL}$. Sebanyak 4,8 $\mathrm{mL}$ dari campuran tersebut dimasukkan ke dalam tabung reaksi yang terdiri dari beragam konsentrasi sampel dan metanol sebagai kontrol. Campuran yang serupa dibuat tanpa $\beta$-karoten dan digunakan sebagai background sampel. Tabung reaksi berisi campuran tersebut kemudian didiamkan pada suhu $50^{\circ} \mathrm{c}$ selama $2 \mathrm{jam}$. Absorban pada 0 menit dari kontrol ( $\left.\mathrm{A}_{0}\right)$ dan sampel $\left(\mathrm{A}_{\mathrm{t}}\right)$ diukur pada panjang gelombang $470 \mathrm{~nm}$. Setelah 120 menit, absorban kontrol ( $\left.\AA_{0}\right)$ dan sampel ( $\left.\AA_{t}\right)$ diukur kembali. Nilai aktivitas dihitung dengan rumus sebagai berikut.

Nilai aktivitas $(\%)=$ $100\left[1-\left(\mathrm{A}_{0}-\mathrm{At}_{\mathrm{t}}\right) /\left(\AA_{0}-\AA_{\mathrm{t}}\right)\right]$

\section{Uji total kandunganfenol}

Uji total kandugan fenol dari ekstrak tanaman dilakukan menggunakan pereaksi Folin-Ciocalteu sesuai dengan metode Singleton et al. (1999). Sebanyak $500 \mu \mathrm{L}$ ekstrak $(1,0 \mathrm{mg} / \mathrm{mL})$ ditambah air suling hingga $8 \mathrm{~mL}$, kemudian dicampur dengan $500 \mu \mathrm{L}$ pereaksi Folin Ciocalteu $(2 \mathrm{~N})$. Campuran tersebut dibiarkan selama 8 menit kemudian ditambahkan 1,5 mL natrium karbonat $20 \%$ dan dibiarkan pada suhu ruang selama 2 jam. 
Absorban diukur pada panjang gelombang 765 $\mathrm{nm}$ dan nilai kandungan fenol dihitung menggunakan kurva kalibrasi yang diperoleh dari berbagai konsentrasi asam galat, kuersetin, dan rutin sebagai standar.

\section{HASIL DAN PEMBAHASAN}

Beberapa uji antioksidan dilakukan untuk mengetahui aktivitas antioksidan dari ekstrak daun T. kiusiana. Metode-metode pengujian yang dilakukan dalam penelitian ini dimaksudkan untuk mendapatkan hasil yang akurat terhadap penentuan potensi ekstrak sebagai antioksidan. Hal tersebut dikarenakan bahwa kandungan senyawa-senyawa kimia di alam sangatlah komplek, sehingga dibutuhkan tidak hanya satu pengujian antioksidan, namun beberapa pengujian antioksidan (Chanda \& Dave, 2009). Sebanyak empat metode pengujian antioksidan digunakan dalam penelitian ini, yaitu uji penghambatan radikal bebas DPPH, kemampuan reduksi, hidrogen peroksida, dan pemudaran $\beta$-karoten. Selain itu, analisis total kandungan fenol pun dilakukan untuk mengetahui hubungan antara kandungan fenol dengan aktivitas antioksidan dari ekstrak T. kiusiana.

\section{A. Uji penghambatan radikal bebas DPPH}

Aktivitas antioksidan dari suatu tumbuhan ditandai dengan salah satunya adalah kemampuannya untuk menangkap radikal bebas. Kemampuan dalam menangkap radikal bebas ini dapat diketahui melalui uji penghambatan radikal bebas DPPH. DPPH adalah radikal bebas yang stabil dan banyak digunakan untuk mengevaluasi kemampuan penangkapan radikal bebas. Penangkapan radikal bebas tersebut ditandai dengan pemudaran warna ungu yang merupakan warna radikal DPPH. Molekulmolekul antioksidan dalam ekstrak dapat menurunkan radikal dengan memberikan elektronnya, sehingga terjadi pemudaran warna larutan uji menjadi warna yang lebih cerah yang menandakan terbentuknya molekul stabil 2,2diphenyl-1-hydrazine (Nithya \& Madhavi, 2017). Molekul yang telah stabil tersebut menghasilkan penurunan absorban pada panjang gelombang $517 \mathrm{~nm}$. Jika aktivitas antioksidan sangat tinggi, warna akan berubah menjadi kuning terang. Dengan demikian, semakin terang warna larutan, maka semakin besar penurunan absorban yang mengindikasikan bahwa kemampuan antioksidan yang tinggi.

Ekstrak daun T. kiusiana menunjukkan aktivitas penghambatan radikal DPPH yang meningkat seiring dengan peningkatan konsentrasi esktrak (Gambar 1).

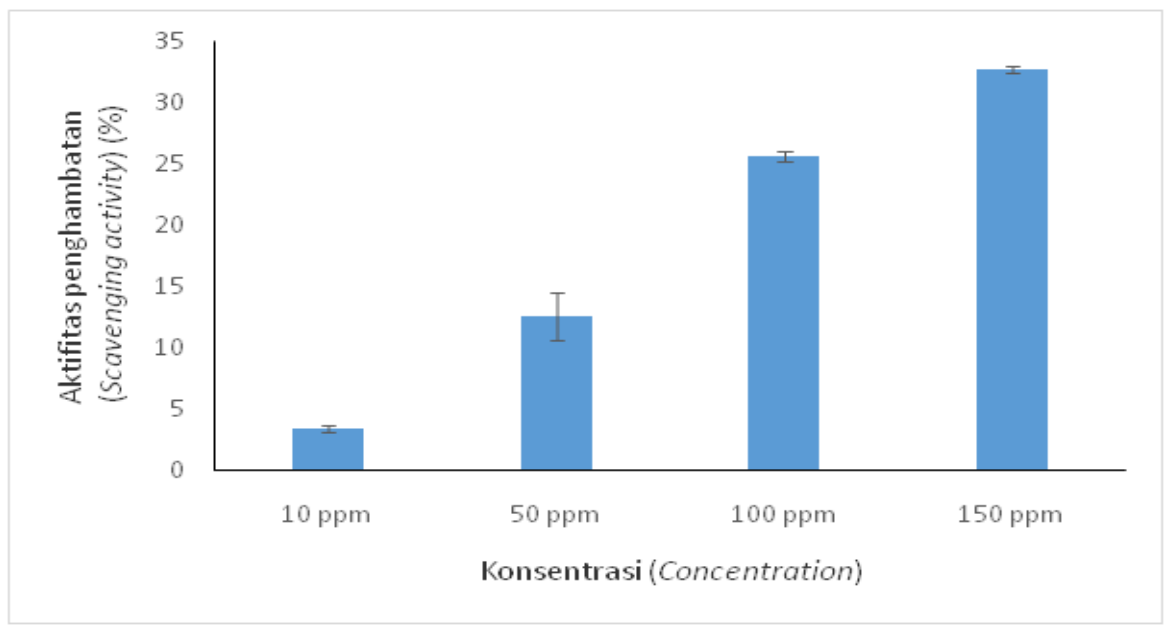

Gambar 1. Aktivitas penghambatan radikal DPPH dari ekstrak T. kiusiana pada berbagai konsentrasi

Figure 1. DPPH radical scavenging activity of T. kiusiana extract at several concentrations 
Aktivitas uji dinilai dalam IC50 yang menerangkan konsentrasi ekstrak yang diperlukan untuk menghambat radikal bebas sebanyak 50\%. Dengan demikian, semakin rendah nilai IC50 berarti semakin tinggi kemampuan antioksidannya. Nilai IC50 dari esktrak daun $T$. kiusiana adalah $232,76 \pm 1,13$ $\mu \mathrm{g} / \mathrm{mL}$. Nilai tersebut lebih tinggi dari kuersetin sebagai standar $(7,4 \pm 0,10 \mu \mathrm{g} / \mathrm{mL})$, yang mengindikasikan aktivitas penghambatan radikal bebas DPPH esktrak daun T. kiusiana lebih rendah dibandingkan kuersetin sebagai standar positif. Meskipun demikian, ekstrak daun T. kiusiana memiliki aktivitas antioksidan.

\section{B. Uji kemampuan reduksi}

Mengukur kemampuan reduksi merupakan salah satu metode pengujian antioksidan.

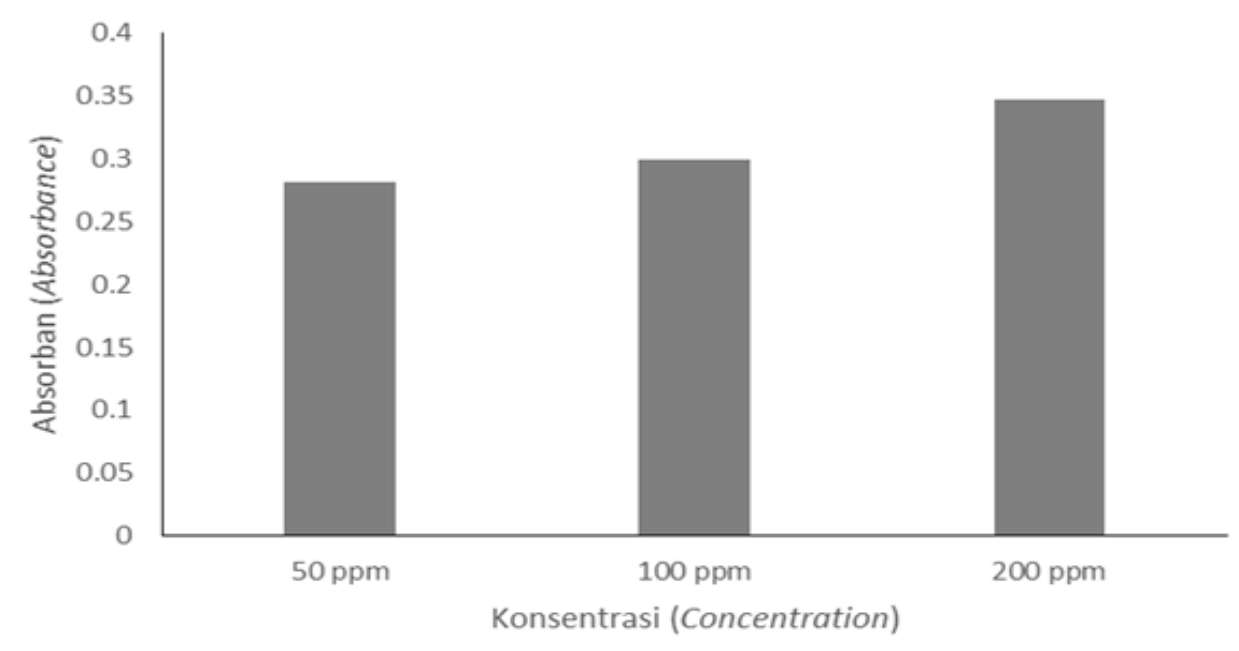

Gambar 2. Aktivitas kemampuan mereduksi dari ekstrak T. kiusiana pada berbagai konsentrasi Figure 2. Reducing power activity of T. kiusiana extract at several concentrations

Uji kemampuan mereduksi ini secara signifikan merefleksikan aktivitas antioksidan dimana ekstrak dengan kemampuan mereduksi yang tinggi artinya memiliki kemampuan yang tinggi dalam memberikan elektronnya untuk menetralkan radikal bebas. Dalam pengujian tersebut, keberadaan antioksidan dalam ekstrak akan mereduksi $\mathrm{Fe}^{3}$ menjadi $\mathrm{Fe}^{2}+$ dengan mendonasikan elektronnya (Ebrahimzadeh et al., 2010). Pada pengujian ini, kemampuan mereduksi esktrak daun T. kiusiana meningkat seiring dengan peningkatan konsentrasi ekstrak (Gambar 2). Nilai kemampuan mereduksi dari esktrak T. kiuisana adalah 53,33 $\pm 1,57 \mathrm{mg}$ QE/g esktrak. Nilai tersebut dinyatakan dalam kesetaraan dengan kuersetin (Quercetin Equivalen/QE).

\section{B. Uji Hidrogen Peroksida}

Untuk mengevaluasi aktivitas antioksidan, kemampuan ekstrak dalam menetralkan hidrogen peroksida pun menjadi penting untuk diketahui. Meski hidrogen peroksida tidak begitu reaktif, namun hidrogen peroksida mampu meningkatkan level hidroksil radikal di sel dan menyebabkan sitotoksisitas (El-Haci et al., 2013). Aktivitas penangkapan hidrogen peroksida merefleksikan kemampuan ekstrak untuk mendonasikan elektronnya kepada hidrogen peroksida $\left(\mathrm{H}_{2} \mathrm{O}_{2}\right)$ dan menetralisasikannya menjadi air (Ebrahimzadeh et al., 2010). Nilai IC50 uji $\mathrm{H}_{2} \mathrm{O}_{2}$ dari ekstrak daun T. kiusiana adalah 304,49 $\pm 4,57 \mu \mathrm{g} / \mathrm{mL}$ (Tabel 1). Nilai tersebut lebih tinggi dari asam galat sebagai 
standar $(52,16 \pm 0,24 \mu \mathrm{g} / \mathrm{mL})$, yang mengindikasikan aktivitas penetralan hidrogen peroksida dari esktrak daun T. kiusiana lebih rendah dibandingkan asam galat.

Tabel 1. Nilai ICso Uji Pemudaran $\beta$-Karoten dan $\mathrm{H}_{2} \mathrm{O}_{2}$ dari ekstrak T. kiusiana Table 1. IC50 value of $\beta$-Carotene Bleaching Assay and Hydrogen Peroxide Assay of

\section{T. Kiusiana extract}

\begin{tabular}{|c|c|c|}
\hline $\begin{array}{c}\text { Sampel } \\
\text { (Sample) }\end{array}$ & $\begin{array}{c}\mathrm{IC}_{50} \text { pada } \mathrm{Uji} \mathrm{H}_{2} \mathrm{O}_{2} \\
\left(\mathrm{IC}_{50} \text { on } \mathrm{H}_{2} \mathrm{O}_{2} \text { assay }\right) \\
(\mu \mathrm{g} / \mathrm{mL})\end{array}$ & $\begin{array}{c}\mathrm{IC}_{50} \text { pada Uji Pemudaran } \beta \text {-Karoten } \\
\left(\mathrm{IC}_{50} \text { on } \beta \text {-Carotene bleaching assay }\right) \\
(\mu \mathrm{g} / \mathrm{mL})\end{array}$ \\
\hline $\begin{array}{l}\text { T. kiusiana } \\
\text { (T.kiusiana) }\end{array}$ & $304,49 \pm 4,57$ & $45,80 \pm 1,68$ \\
\hline $\begin{array}{l}\text { Asam galat } \\
\text { (Gallic acid) }\end{array}$ & $52,16 \pm 0,24$ & $65,93 \pm 3,85$ \\
\hline
\end{tabular}

\section{Uji Pemudaran $\beta$-karoten}

Dalam pengujian antioksidan, $\beta$-karoten biasa digunakan untuk mengetahui kemampuan antioksidan suatu ekstrak atau senyawa dalam menghambat pemudaran warna $\beta$-karoten. Keberadaan antioksidan akan menghambat pemudaran tersebut dengan menstabilisasi radikal bebas linoleat dan radikal bebas lainnya yang terbentuk dalam sistem pengujian yang akan menyerang ikatan rangkap dua dari $\beta$-karoten yang menyebabkan pemudaran (Jayaprakasha et al., 2001). Ekstrak daun $T$. kiusiana memiliki aktivitas penghambatan pemudaran $\beta$-karoten dengan

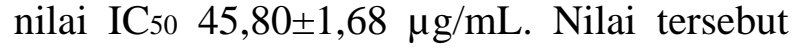
lebih rendah dari asam galat sebagai standar $(65,93 \pm 3,85 \mu \mathrm{g} / \mathrm{mL})$, yang mengindikasikan aktivitas pemudaran $\beta$-karoten dari esktrak daun T. kiusiana lebih tinggi dibandingkan asam galat.

Berdasarkan pengujian-pengujian antioksidan di atas, dapat diindikasikan bahwa ekstrak daun T. kiusiana memiliki aktivitas antioksidan. Beberapa literatur menyampaikan korelasi yang positif antara antioksidan dan kandungan fenolik (Prihantini et al., 2014; Basma et al., 2011, Cai et al., 2004). Oleh karena itu, untuk mengetahui faktor yang berpengaruh terhadap aktivitas antioksidan ekstrak daun T. kiusiana yang relatif sedang tersebut, diperlukan analisis total kandungan fenolik dalam ekstrak tersebut.

\section{Uji Total Kandungan Fenol}

Senyawa-senyawa fenolik diketahui terkandung dalam sebagian ekstrak tanaman. Senyawa fenolik telah dipertimbangkan memiliki peranan penting dalam aktivitas antioksidan. Untuk mendapatkan hasil yang lebih akurat, pengukuran total kandungan fenolik perlu dilakukan dengan menggunakan kesetaraan terhadap beberapa senyawa atau standar.

Tiga senyawa yang telah diketahui sebagai antioksidan yang bagus adalah asam galat, rutin, dan quercetin (Sajeeth et al., 2010; Tadera et al., 2006; Li et al., 2009). Asam galat dan kuersetin merupakan senyawa yang biasa digunakan dalam menilai total kandungan fenolik dalam tanaman (Chanda \& Dave, 2009).

Selain kedua senyawa fenolik tersebut, dapat dipertimbangkan pula bahwa glikosida dari senyawa fenolik yang aktif antioksidan terkandung dalam ekstrak tanaman. Oleh karena itu, rutin sebagai glikosida dari kuersetin juga digunakan dalam penelitian ini.

Hasil pengujian total kandungan fenolik menunjukkan bahwa ekstrak daun T. kiusiana memiliki kandungan fenolik yang setara dengan asam galat, rutin, dan kuersetin secara berurutan yaitu 49,29 $\pm 3,82 \mathrm{mg}$ GAE/g; $36,57 \pm 3,01 \mathrm{mg} \mathrm{RAE} / \mathrm{g} ; 90,44 \pm 7,23 \mathrm{mg}$ QAE/g (Tabel 2). 
Tabel 2. Total kandungan fenol dari ekstrak T. kiusiana

Table 2. Total phenolic content of $\mathrm{T}$. Kiusiana extract

\begin{tabular}{rccc}
\hline \multirow{3}{*}{$\begin{array}{c}\text { Ekstrak } \\
\text { (Extract) }\end{array}$} & \multicolumn{3}{c}{$\begin{array}{c}\text { Total Kandungan Fenol } \\
\text { (Total Phenolic Content) }\end{array}$} \\
\cline { 2 - 4 } & $\begin{array}{c}\text { GAE } \\
(\mathbf{m g ~ G A E} / \mathbf{g})\end{array}$ & $\begin{array}{c}\text { RAE } \\
(\mathbf{m g ~ R A E} / \mathbf{g})\end{array}$ & $\begin{array}{c}\text { QAE } \\
(\mathbf{m g} \text { QAE/g) }\end{array}$ \\
\hline $\begin{array}{l}\text { T. kiusiana } \\
\text { (T.kiusiana) }\end{array}$ & $49.29 \pm 3.82$ & $36.57 \pm 3.01$ & $90.44 \pm 7.23$ \\
\hline
\end{tabular}

Keterangan (remark): GAE= ekuivalen asam gallat (Gallic acid equivalent); $R A E=$ ekuivalen rutin (Rutin equivalent); $Q A E=$ ekuivalen kuersetin (Quercetin equivalent)

Bila dibandingkan dengan penelitian sebelumnya (Prihantini et al., 2014) dimana telah dilakukan uji bioaktivitas dari ekstrak metanol dari daun tanaman-tanaman subtropis lainnya, nilai total kandungan fenol dari ekstark daun T. kiusiana tersebut termasuk rendah. Rendahnya nilai total kandungan fenolik pada ekstrak daun $T$. kiusiana dapat menjelaskan aktivitas antioksidan yang tidak terlalu tinggi. Meskipun rendah akan kandungan fenolilk, ekstrak daun $T$. kiusiana memiliki aktivitas antioksidan. Aktivitas antioksidan tersebut dapat berasal dari senyawa-senyawa selain fenolik yang berpengaruh dalam aktivitas antioksidan seperti vitamin, minyak atsiri, karotenoid, alkaloid, terpenoid, protein, dan sebagainya (Basma et al., 2011; Hassimoto et al., 2005). Selain jenis senyawa-senyawa yang terkandung dalam ekstrak tanaman, interaksi antar senyawa baik antagonistic ataupun synergetic interaction dapat memberikan kontribusi pada aktivitas antioksidan.

\section{KESIMPULAN DANSARAN}

\section{A. Kesimpulan}

Penelitian ini membuktikan bahwa dalam jangkEkstrak metanol dari daun T. kiusiana memiliki aktivitas yang sedang pada uji-uji antioksidan seperti penghambatan radikal DPPH, uji kemampuan reduksi, uji hidrogen peroksida, and uji pemudaran $\beta$-karoten. Kemampuan yang sedang tersebut salah satunya diindikasikan karena kandungan total senyawa fenolik yang rendah. Pada laporan penelitian ini, pertama kali disampaikan pengujian aktivitas antioksidan dari ekstrak metanol daun T. kiusiana. Penelitian ini juga dapat mendukung upaya penemuan dan penyediaan obat-obatan alami dari tumbuhan.

\section{B.Saran}

Untuk mengetahui potensi bioaktivitas lainnya dari T. kiusiana, maka perlu dilakukan pengujian bioaktivitas lain seperti uji anti bakteri, anti jamur, dan anti diabetes.

\section{UCAPAN TERIMA KASIH}

Penulis mengucapkan terima kasih kepada Rizna Triana Dewi, Ph.D atas bantuannya dalam penyelesaian penelitian ini.

\section{DAFTAR PUSTAKA}

Basma A. A., Zakaria Z., Lactha Y. L., \& Sasidharan S. (2011). Antioxidant Activity and Phytochemical Screening of The Methanol Extracts of Euphorbia hirta L. Asian Pasific Journal of Tropical Medicine, 386-390.

Brahmachari G. (2012). Natural Products in Drug Discovery: Impacts and Opportunities - an Assesment. In Bioactive Natural Products: Opportunities and Challenges in Medicinal Chemistry, 1st Ed., Ed., G. Brahmachari, World Scientific Publisher, $\mathrm{S}$ i n g a $\mathrm{p}$ o $\mathrm{r}$ e, $1-199$.

Cai Y., Luo Q., Sun M., \& Corke H. (2004). Antioxidant activity and phenolic compounds of 112 traditional Chinese medicinal plants associated with 
anticancer. Life Science, 74, 2157-2184.

Chanda A. Y. Y. \& Dave R. (2009). In vitro models for antioxidant activity evaluation and some medicinal plants possessing antioxidant properties: An overview. African Journal of Microbiology Research, 3, 981-996.

Ebrahimzadeh M. A., Nabavi S. M., Nabavi S. F., Bahramian F., Bekhradnia A. R. (2010). Antioxidant and free radical scavenging activity of $H$. officinalis $L$. var. Angustifolius, V. Odorata, B.Hyrcana, and C.Speciosum. Pakistan Journal of Pharmaceutica Science, 23(1), 29-34.

El-Haci I. A., Bekkara F. A., Mazari W., \& Gherib M. (2013). Phenolics content and antioxidant activity of some organic extracts of endemic medicinal plant Anabis aretioides Coss. And Moq. From Algerian Sahara, Pharmacognosy Journal, 5, 108-112.

Gurnani N., Mehta D., Gupta M., \& Mehta B. K. (2014). Natural Products: Source of Potential Drugs. African Journal of Basic \&Applied Sciences, 6(6), 171-186.

Hassimoto N. M., Genovese M. I., Lajolo F. M. (2005). Antioxidant activity of dietary fruits, vegetables and commercial frozen pulps. Journal of Agriculture and Food Chemistry, 53, 2928-2935.

Harvey A. L. (2008). Natural product in drug discovery. Drug Discovery Today, 13(19/20), 894-901.

Jayaprakasha G. K., Singh R. P., \& Sakariah K. K. (2001). Antioxidant activity of grape seed (Vitis vinifera) extracts on peroxidation models in vitro. Food Chemistry, 73,285-290.

Li Y. Q., Zhou F.C., Gao F., Bian J.S \& Shan F. (2009). Comparative evaluation of quercetin, Isoquercetin and rutin as inhibitor of $\alpha$-glucosidase. Journal of Agricultural and Food Chemistry, 57,11463-11468.

Newman D. J. \& Cragg G. M. (2016). Natural Products as Sources of New Drugs from 1981 to 2014, Journal of Natural Products, 79, 629-661.

Nithya P. \& Madhavi C. (2017). Antioxidant activity of 3-arylidene-4-piperidones in the 1,1-diphenyl-2-picrylhydrazyl scavenging assay. Journal of Taibah University for Science, 11, 40-45.

Ortholand J. Y \& Ganesan A. (2004). Natural products and combinatorial chemistry: back to the future. Current Opinion in Clinical Biology, 8,271-280.

Pattrick, Graham. (2001). Medicinal chemistry. BIOS Scientific publisher. UK.

Prihantini A. I., Tachibana S., \& Itoh K. (2014). Evaluation of Antioksidant and $\alpha$-Glucosidase Inhibitory Activities of Some Subtropical Plants. Pakistan Journal of Biological Sciences, 17(10), 11061114.

Ruch R. J., Cheng S. J., \& Klavning J. E. (1989). Prevention of cytotoxicity and inhibition of intracellular communication by antioxidant catechins isolated from Chinese green tea. Carcinogens, 10,10031008.

Sajeeth C.I., Manna P.K., Manavalan R., Jolly C.I. (2010). Quantitative estimation of gallic acid, rutin and quercetin in certain herbal plants by HPTLC method. Der Chemica Sinica, 1,80-85.

Shimada M. Ozawa M. Iwamoto K. Fukuyama Y. Kishida A. Ohsaki A. (2014). A lanostane triterpenoid and three cholestone sterols from Tilia kiusiana. Chemical and Pharmaceutical Bulletin, 62(9), 937-941.

Singleton V. L., Orthofer R., \& Raventos R. M. L. (1999). Analysis of total phenols and other oxidation substrates and antioxidant by means of Folin-Ciocalteu reagent.Methods in Enzymology, 299, 152-178.

Tadera K., Minami Y., Takamatsu K., Matsuoka T. (2006). Inhibition of $\alpha$-glucosidase and a-amylase by flavonoids. Journal of Nutritional Science and Vitaminology, 52,149-153.

Yen G. C. \& Chen H. Y. (1995). Antioxidant activity of various tea extracts in relation to their antimutagenicity. Journal of Agriculture and Food Chemistry, 43,2732. 